'Never Was Piping So Sad, and Never Was Piping So Gay'

Author(s): E. C. Carmichael

Source: The Celtic Review, Vol. 2, No. 5 (Jul., 1905), pp. 76-84

Stable URL: http://www.jstor.org/stable/30069862

Accessed: 27-06-2016 09:16 UTC

Your use of the JSTOR archive indicates your acceptance of the Terms \& Conditions of Use, available at

http://about.jstor.org/terms

JSTOR is a not-for-profit service that helps scholars, researchers, and students discover, use, and build upon a wide range of content in a trusted digital archive. We use information technology and tools to increase productivity and facilitate new forms of scholarship. For more information about JSTOR, please contact support@jstor.org.

is collaborating with JSTOR to digitize, preserve and extend access to The Celtic Review 


\title{
' NEVER WAS PIPING SO SAD, AND NEVER WAS PIPING SO GAY'
}

\author{
E. C. Carmichael.
}

THE 'people of peace' have ever been held to be gifted with music. When their green hillocks are open, music and song may be heard so sweet and alluring that the incautious mortal, unable to resist their charm, goes into the bower to join in the merriment and remains a half willing if sometimes unwitting prisoner, till some accident or a friend releases him. Then he finds that he has been a year and a day, seven, nine, or even twenty years in the fairy knoll, while he thought 'twas but an hour or a night, so beguiling were the music and the dance and the little folks themselves! Many instruments the fairies have too-pipes and harps and other wind and stringed instruments, and all so greatly superior to those of human make that a fairy instrument is a coveted treasure among the people of earth. But not many of these have been bestowed on the children of men, and the few seem all to have been given by the women of faery. Here are some stories of fairy pipes which I have heard in the Hebrides, and now translate from Gaelic.

The famous Maccrimmons, pipers to the Macleods of Macleod, owed their renown in music to a fairy. When the Macleod of the day returned from one of the Crusades, he brought with him from Cremona a servant who, quite according to Highland usage, became known by the name of his home. Cremon married in Skye, and when his son was old enough he sent him to the school or college of music at Boreraig, in Glendale, to learn pipe music. This school was celebrated throughout Alban and Erin and Sasunn and the divisions of Europe, and had many pupils, especially for the bagpipes. Cremon wished his son to be a good piper, that he might obtain the honourable position of piper to Macleod of Macleod, for musicians were highly esteemed among the ancient Gaels, and the office of musician to a great chief was 
one of much honour and dignity, conferring on its holder many valued privileges and possessions.

But 'Mac Cremmain,' or MacCrimmon, as he was called -the son of Cremon-had no aptitude for the Highland pipes, they were foreign to his race and nature, and his fellow-pupils held rather aloof from the strange lad whose ways were more of his father's land than of his mother's. So the lad was sorrowful and miserable, and he often went out with his sorrow and his misery to the lee of a green knoll at a little distance from the college, to brood and to wish that he could play the pipes like his fellow-students.

One day the 'Piobaire mor'-great Piper, as the head of the college was called-got an invitation to the marriage of a great Chief, and he was asked to bring some of his pupils to help to entertain the guests. There was much excitement in the college, and much speculating and rivalry among the lads as to who would be thought worthy to go. When the 'Piobaire mor' announced his choice of pupils, MacCrimmon's name was not among them, and though he had not really expected to be among those chosen, he was heavy and sad with disappointment. After the others had set out for the Chie f' dun MacCrimmon could not longer restrain his feelings, and he threw himself down in his lonely haunt on the green hillock and wept the tears-the bitter tears-of disappointed hope. While he was dead to all around, he was startled by the sound of a voice asking why he grieved so greatly. Looking up he saw a woman, small indeed, but of beautiful face and form, dressed in a soft green gown, gazing at him with pity shining in her eyes, and peace and love in her face. He knew she was one of the 'sithe' or fairies, and he was afraid. But she looked at him so tenderly and spoke to him so kindly that he poured out before her all his heart's heavy sorrow. He told her that he could not master the bagpipes, and that he played so badly that he had not been taken to the wedding, that the other pupils were not friendly, and that he was altogether miserable. The kind little fairy put her slender hand on the lad's dark 
head and comforted him, and she told him he would play better than any of the other students some day. She then gave him a chanter, the like of which had never been seen before by mortal eyes. She told him that the possessor of that chanter would carry with him 'Buaidh na Piobaireachd'the championship of piping. But should a word ever be said in disparagement of the chanter she would instantly take it back, with all the skill it conferred. Then the lovely green-robed fairy disappeared as mysteriously as she had come, leaving the lad too much lost in surprise to think of thanking her.

MacCrimmon hurried back to the college, put the chanter in the pipes and blew it. To his delight he found he could play, and not merely the tunes he had tried so unsuccessfully to learn but tunes he had never tried before, and even new tunes that no one had ever heard; and he could play them, too, better than any one he had ever listened to-better than the 'Piobaire mor' himself! His happiness was now as great as his grief had been before, and he could hardly sleep or eat, he only wished to play his wonderful chanter night and day. When his teacher and fellowpupils returned after a few weeks' absence-for the festivities connected with the marriage of a great Chief were somewhat prolonged-they could scarcely believe their eyes and ears. The stupid foreign lad who could not play when they left, could now play better than the great Piper of the famous college of Boreraig! Quick questions were asked and the lad told his tale. All knew of the music of the 'sithean' or fairy bower, and all knew that he to whom a 'sithe' gave the gift of music was indeed endowed beyond all hope of rivalry. The wonderful chanter was examined and commented upon, but no one could make out of what material it was made. It did not seem to be made of metal, of wood, or of stone.

Those who had formerly jeered at MacCrimmon now envied him and vainly tried to imitate his playing. But it was useless. MacCrimmon could make his pipe move the hearts of his hearers so that they had no will but as it 
impelled them. Did he play 'Geantraighe' they danced and sang for joy and pure happiness of mind and body. Did he play 'Suaintraighe' they slumbered peacefully and with a happy smile dreamt of their dear ones and of pleasant days with their comrades. Did he play 'Gultraighe' a wild passionate longing and a great sorrowful lamenting came into every heart. Never was such music heard before. From far and near people came to hear it and to wonder at it, and MacCrimmon's music played with their souls as the north wind plays with the leaves of the birch tree on the brown mountain side.

MacCrimmon became piper to Macleod of Macleod, and his son, and his son's sons succeeded him for many generations, and the fairy chanter descended as the most valued possession of the family. Their fame was known wherever music was loved. The college at Boreraig, where the first Maccrimmon had been so backward a learner, was under their teaching, and people came from Erin and from Sasunn and from all the divisions of Europe to learn music in Skye.

Before students were considered fit to leave the collegeand the several courses lasted from four to ten years-they had to be able to play one hundred and ninety-nine tunes, some of them very intricate, besides exercises, and to be masters of theory and composition. It is said that in later days the Maccrimmons gave diplomas to successful graduates. These diplomas had on them pictures of Dunvegan Castle, of the galley of Macleod, and of various musical instruments, a seal, and the name of the holder, with the dates of entrance to and departure from the college. ${ }^{1}$ Two of the Macintyres of South Uist, hereditary musicians to Clanranald, were among the last students at this school-about the beginning of ' the '45.' Four cows are said to have been paid for their education there.

A Skye tradition says that it was practically the last of the Maccrimmon pipers who composed the beautiful and

\footnotetext{
${ }^{1}$ A family of the name of Robertson in Inverness-whether town or county I do not know-is said to possess one of these certificates.
} 
pathetic 'cumha' or lament known by his name, and that it has a double prophetic meaning in that it was a lament for himself, for he foresaw that he would be one of the many to give up life in the ill-fortuned Stuart wars, and also for the fairy's gift. This Maccrimmon was the only man killed at the Moy Rout, and after his death his son inherited the chanter and the office. On one occasion Macleod of Dunvegan and Macleod of Raasay were returning in the Dunvegan galley after visiting the chief of Abercrossain, now Applecross. Maccrimmon, as usual, was with his master and was asked to ' seid suas'-blow up. He sat on the prow, the piper's seat, and began playing. But the wind was so strong and the sea so rough in the Sound, that his fingers kept slipping off the chanter with the rolling of the galley. At last it got so bad that MacCrimmon threw down his pipes in anger, and began abusing the chanter because he could not keep his fingers on it. While he was speaking the chanter gave a leap over the side of the vessel into the sea. MacCrimmon remembered, too late, the command handed down by his fathers, for the chanter had gone as the fairy giver had said, so many generations before, that it would. And with the chanter went the championship of piping; and the home of the Maccrimmons is desolate, and their hereditary office unfilled. The set of pipes, called 'an oiseach' (oinseach ?) with which the fairy chanter was used, is carefully kept at Dunvegan. Will the green-robed lady ever relent and return the chanter, and with it the championship of piping?-though indeed there are now no Maccrimmons in Skye to hold them.

Another legend is somewhat different. There was on a time a great gathering of pipers to be at Dunvegan, and there was no piper better than another far or near, on mainland or island, who did not take the road for the Dun. When the day came, there surely was the multitude of people-Macleods and strangers. It happened that Macleod of Dunvegan had a herd boy who was very wild to see the heros of the drones and to hear them for himself, and he asked Macleod if he might stay at home that day. "Thou little rascal that 
thou art,' said Macleod, 'thy work is tending the cattle; and good as piping is, it cannot keep the bulls from fighting, nor the calves from falling into the ditches. Away, boy, and do not return here till the black herdsman night brings thyself and the cattle home together.' The lad went away downcast and disappointed, and drove the cattle to the shieling. $\mathrm{He}$ sat down on a fairy knoll and put the black chanter of the pipes in his mouth. But he had a scarf round his neck and his emotion was so great that his breath came in sudden jumps and leaps, and the chanter was but a bad stepmother to the pipes. At last he threw it away and hid his head in a heather tuft for fear the dogs and the calves would see and mock at him. He had hardly put his head down when the 'sithean' opened and the pretty little lady of melody came out. She put her white hand on the boy's head, 'Bonnie lad,' she said, ' what has put against thee, and what harm has the black chanter of the pipe done thee?' He told her everything as it was, and how he himself wished things were. The lovely fairy then gave him his choice of three championships - the championship of sailing, so that his boat of spotted yew would cut a slender oaten straw, so good her steering, and that her keel would scrape as with sharp knives the limpets from the tops of the hidden rocks; or the championship of battle, so that the raven of the Dun would be satiated with the blood of his enemies every day on which the sun rose or darkness lay ; or the championship of piping, so that he would bring the birds from the trees and that he would give peace and relief to wounded men and pain-worn women. The boy did not doubt nor delay in deciding which was better, the championships of sailing or of fighting, but without a word backward or forward he chose the championship of piping. Then the beautiful little fairy said, 'Thou hast thy wish from this time,' and she went back into the bower, and the knoll was as it had been before. The boy stared at the place where she had been, but there was nothing to see-only soft green grass and flowers. He took up his pipes and played. But there was the wonderful thing! The music that was

vOL. II. 
there! He had never known that there could be such music. And as he played the cattle and the dogs, and the deer of the hill, and the birds of the air, and the creeping things of the earth came round him to listen. After he had played for a long time he thought he would go away back to Dunvegan, for he felt he must tell everybody about the wonderful fairy and show them the gift she had given him. It was there the great piping was, on the green sward, and the many pipers from all places, and it was there the people were, gentle and simple in their crowds listening to them. When Macleod saw the herd lad with his pipes under his arm listening with the others he was angry, and he asked him why he had left the cattle and come to the castle when he had given him fast orders to stay at the shieling. The lad answered that he could not keep away from the piping any longer, and that he felt sure he could play as well as the best piper there. Macleod laughed at the boy's presumption, but to punish him, told him to blow up, adding that if he failed to make good his boast he would get a hard thrashing. The boy blew up, and he played, and that was the playing and that was the music! At first the other pipers laughed, then they stared, then a great silence fell over them. When he had finished they all admitted that the herd lad had indeed 'buaidh na piobaireachd' the championship of piping, and they eagerly crowded round him with questions. He told his tale, and then all said that he to whom the fairy queen of melody gave her gifts was indeed a musician, and they piped no more that day, for they said, 'This young lad shames us all.' The lad was taken from herding the cattle and made piper to Macleod of Dunvegan, and a good farm with its share of cattle and horses and sheep and goats was given to him and to his heirs so long as they should continue pipers to Dunvegan and follow its chief in war and in peace.

The hereditary musicians to the Macdonalds of Clanranald were Macintyres, and they too, got a gift of music from a fairy. This is how it was. A son of the musician-for the Macintyres were musicians before they got the fairy gift-had 
a sweetheart of the little people. She was a very beautiful lady with a skin like the fair breast of the kittiwake and cheeks like the wild red rose by the mountain stream. Her eyes were of the deep blue of the juniper-berry, and her long hair was the colour of soft, pale, unwrought gold, that glimmered in the sun and fell about her like golden mist. Her voice was like sweet mellow music. The gown she had was of soft trailing stuff of the pure colour of the green sea when it lies over white sand, and as she walked it was like the moving light on a sloping field of long, green grass when the low wind blows over it and the sun's brightness is gently veiled. 'Her steps were the music of song,' and her fingers were so deft and quick that she could prepare a fleece of wool, pick it, and card it, and spin it, and dye it, and weave it into a big tartan plaid all in an hour by the sun; and her head and mind were so clever that she knew even what was happening far off. One evening when the fairy and young Macintyre were walking on the green flowery machair near to the farm of Smearclaid in South Uist that his father held as Clanranald's musician, she told him that strangers from Erin over the sea were coming to his father's house to hear if the Macintyres were indeed as good musicians as was reported. 'But,' the fairy said, 'I will give you this reed, and you must go home and put it in your father's pipes and play to the strangers. Then they shall see that report said not enough of the music of the Macintyres.' For the pretty little lady was jealous for the fame of her lover's family.

The young man did as she told him. He went home, and there, sure enough, were the strangers being hospitably entertained with food and drink after their journey from far lands. After they had eaten, and while they were resting, the lad said to his father that he would now take the pipes and amuse the strangers who had come home to them from over the waves. 'You play!' said the father; 'you could never play anything in your life-you will just cause us to be laughed at.' The young man however prepared the pipes and put in the fairy reed, and he played the music that 
astonished every one. His family listened with surprise and delight, and the strangers were without speech. They had never heard or dreamt of such nobly sweet music-music which spoke to their souls and told them good and great things that they had never felt before in the world. It seemed not of earth, so sweet and strange it was. And the lad did it so simply - he just blew as usual, and he moved his fingers with no more trouble than any one else, yet he played fast, loud, joyful music, and slow, solemn, sorrowful music. It was like the music of 'Tir nan Og'-the Land of the Ever-young.

After he stopped playing his listeners sat silent for a long space, for they could not speak. But when the spell left them and the strangers' speech came back, they whispered to each other that none dared compete against that, and that they themselves must not touch the pipes. So, as it was the mannerly custom among the Gaels to invite strangers to show their skill, they soon took leave of Macintyre and his family, for it was considered rude to refuse to play when asked. After they had, with much pretended hurry, bid good health be with their entertainers, they hastened to their coracle and sailed away out of that, saying to each other, 'If that is what the lad does who, they say, cannot play, what can the old man's music be?' and they returned no more to South Uist, for they themselves were known musicians-but they had no fairy reed or chanter!

\section{BOOK REVIEWS}

Higher Grade Readings in Gaelic, with Outlines of Grammar. Edited by Alexander Macbain, LL.D. Northern Counties Publishing Office, Inverness : 1905 . 1s.6d. net.

Boys and girls in Highland schools speak Gaelic fluently, in pronounced dialect form for the most part. How best to utilise this acquirement of theirs in order to further their mental training and general culture is a vital question in the education of these children. Hitherto it has been practically ignored. But the Scottish Education Department has, by a recent Minute, offered a Leaving Certificate in Gaelic, and Dr. Macbain, a foremost Gaelic 